\title{
THE CONSISTENT ESTIMATION OF INCOME ELASTICITY OF ENVIRONMENTAL AMENITIES IN URUGUAY
}

\author{
Daniel Miles \\ Universidad de Vigo \\ Andrés Pereyra \\ Universidad de Uruguay \\ Máximo Rossi \\ Universidad de Uruguay
}

Resumen: Estamos interesados en la estimación de la elasticidad ingreso de la demanda de bienes ambientales. Resulta novedoso la aplicación de métodos econométricos que toman en cuenta el problema de los errores de medición cuando se estiman dichas elasticidades, errores que son frecuentes en los datos microeconómicos, y que no son totalmente considerados en la literatura sobre el tema. Nuestro objetivo es discutir si el error de medición tiene un efecto significativo en las elasticidades. Se utiliza información de la Encuesta de gastos e ingresos, 1994 - 1995, realizada por el Instituto Nacional de Estadística.

Abstract: In this paper we are concerned with the estimation of income elasticities of environmental amenities. The novelty is the application of econometric methods that take into account the problem of measurement errors when estimating these elasticities, which is common in microeconomic data and is not usually considered in the applied literature related to this issue. Our aim is to discuss whether measurement errors have significant effects on income elasticities. Data from the Expenditure Budget Survey of Uruguay, 1994 - 1995, are used.

JEL Classifications: C20, D12 


\section{Introduction}

In the environmental literature there has been an increasing interest in analyzing the income elasticity of environmental amenities, and particularly, of the willingness to pay for environmental improvements (see, among others, Kriströrom and Riera, 1996 and references therein). In this paper we are concerned only with estimating the income elasticity of environmental amenities, leaving aside the discussion about its use as an approximation of the elasticity of willingness to pay (Flores and Carson, 1995). Specifically, in this paper we discuss whether estimated income elasticities are noticeably affected by the measurement error problem, which is present when estimating demand equations, or by the way household characteristics are introduced in the parametric specifications.

Basically, most studies estimating elasticities do not take into account the measurement error problem that appears when approximating consumption by observed expenditure or income. This problem is present whenever we use microecenomic budget data to estimate demand equations (see Miles, 1998). When the problem of measurement error is taken into account, the traditional estimation procedure is the instrumental variables method (see, for example, Curiel 1997 or Kriström and Riera, 1996). The problem is that failing to take into account the measurement error problem or correcting it by the traditional instrumental variables method leads to inconsistent estimates under the usual demand specifications (Hausman, Newey and Powell, 1995; Lewbel, 1996). The novelty of this paper is that we apply economically coherent methods that lead to consistent estimates of the paramenters of demand equations. Our simple concern is whether the elasticities are sensitive to the different methods used for correcting this problem.

The paper is organized in three sections. In the first section, we briefly review the literature related to the functional forms of Engel curves and the econometric methods applied. In the second section we apply these methods to the Uruguayan Expenditure Budget Survey, 1996 data. Finally, in the third section we conclude.

\section{The functional form of the Engel curve and the methods for correcting measurement errors}

The functional forms most commonly used in applied work are those derived from the PIGLOG specification, nesting the Working-Leser, 
the translog or the almost ideal specification (Deaton and Muellbauer 1980 and Pollak and Wales, 1992). Basically, these functional forms are stated in terms of the budget share as a linear function of total expenditure.

Recently, Banks, Blundell and Lewbel (1997) proposed a generalization showing that the quadratic in logarithms Engel curve specification is preference consistent. ${ }^{1}$ This quadratic in logs specification has been widely used in empirical estimations of demand systems (Fry and Pashardes, 1992). This specification is given by

$$
w_{k}^{*}=C_{k} / C=\beta_{0 k}+\beta_{1 k} \ln (C)+\beta_{2 k} \ln (C)^{2}+\varepsilon_{k} \quad k=1, \ldots K,
$$

where $w_{k}^{*}$ is the budget share defined as the ratio of consumption allocated in good $k, C_{k}$, to total consumption, $C, \varepsilon_{k}$ is a disturbance term which satisfies $E^{\prime}\left(\varepsilon_{k} \mid C\right)=0$, and $K$ is the total number of goods.

The problem that appears when trying to estimate equation (1) is that consumption in good $k, C_{k}$, and total consumption, $C$, are not observable. Usually, in applied work these quantities are approximated by the expenditure in good $k, G_{k}$ and total expenditure, $G$, introducing a measurement error problem, i.e., $G_{k}=C_{k}+U_{k}$, where $U_{k}$ is the measurement error of consumption of good $k$. Therefore, the estimation method should take care of the measurement error so as to produce consistent estimators.

Traditionally, measurement error has been corrected by means of the traditional instrumental variable method. However, in the context of a model that is linear in parameters and nonlinear in variables, this method produces inconsistent estimates. 'To see this, let the measurement error equation for total consumption be $G=C U$. Substituting in equation (1) and operating we get

$$
w_{k}=\beta_{0 k}+\beta_{1 k} \ln (G)+\beta_{2 k} \ln (G)^{2}+\eta_{k}
$$

with

$$
\eta_{k}=\varepsilon_{k}+\left(w_{k}-w_{k}^{*}\right)-\beta_{1 k} \ln (U)-2 \beta_{2 k} \ln (G) \ln (U)+\beta_{2 k} \ln (U)^{2} .
$$

The instrumental variables, $Z$, should verify simultaneously $E$ $\left(\eta_{k} Z\right)=0$ and $E(Z \ln (G)) \neq 0$. But, given that $\eta_{k}$ is a function of

1 Gorman, 1981 and Lewbel, 1987 have shown that the quadratic in logs specification is preference consistent. 
$\ln (G)$, it does not seem possible to find an instrumental variable that is simultaneously correlated with total expenditure and uncorrelated with a function of it (Miles, 1998). That is, the traditional instrumental variable method is not feasible when the model is linear in the parameters and nonlinear in the mismeasured variable.

An additional problem that complicates the application of instrumental variables to Engel curves is given by the fact that the measurement error affects the dependent variable nonlinearly That is, given that $w_{k}^{*}=C_{k} / C$, the measurement error on the dependent variable can not be separated additively, as is done in the classical context of measurement error problems.

In this paper we apply three newly developed approaches for taking care of measurement errors in models that are non-linear in variables. In the first place, we apply the instrumental variable method developed by Hausman et al. $(1991,1995)$, which corrects the measurement error problem when it affects the independent variables nonlinearly, assuming that measurement errors do not affecting the dependent variable. In the second place, we apply the method proposed by Lewbel (1996), which corrects for measurement errors that affect both the dependent and the independent variables nonlinearly. The econometrics methods used in this paper are developed in the appendix $\mathrm{B} .{ }^{2}$ Basically, the concern of this paper is to observe whether applying these methods, together with ordinary least squares and the traditional instrumental variable method, affects the conclusions with respect to the income elasticity of environmental amenities, as well as to observe the sensitiveness of these estimations. That is, our interest is to observe whether the economic conclusions are affected by the method used for estimating the elasticities. In the next section we present the results of applying these methods.

\section{The income elasticity of environmental amenities}

In this section we present the results of applying the different methods described above to the estimation of income elasticities for environmental amenities. The data used was obtained from the 1996 Uruguayan expenditure budget survey, which is undertaken by the Instituto Nacional de Estadistica de Uruguay and consists of 3749 observations. This survey covers urban households in towns with more than 10000 inhabitants at the time of the 1995 Census. The environmental amenities considered are:

2 The estimations were programmed with Gauss 2.5 
Camping 1: Rent of campgrounds, day trips, hunting permits.

Camping2: Rent of campgrounds, day trips, hunting permits and goods forcamping and hunting.

Recreation: Recreation expenditures, travel expenses, sports clubs fees, minor travel expenses.

Env1: Camping2 plus recreation.

Electricity: Electricity expenditures.

Gas: Gas expenditures.

Car: Fuel and car manteinance expenditures.

It is clear that household characteristics affect consumer behavior with respect to these goods. There are basically two ways in which an equation could be estimated to take care of household characteristics (Pollak and Wales, 1992). One is to consider the sample as a whole, where the characteristics are introduced as dummy variables in the equation to be estimated (parametric approach). The other is to divide the sample into homogenous subsamples, depending on household characteristics (non parametric approach). This last approach, provides a better understanding of the effect of household characteristics on their consumption behaviour. In this paper we follow this last approach, subdividing a sample of households of married couples in which the head of the household is employed, into subsamples depending on the age of the partner, the number of children and whether they live in Montevideo, the capital, or in the rest of the urban country (RUC). This subdivision included eight subsamples, the composition of which is presented in table 1.

Table 1

Mean expenditure on environmental commodities in 1990 prices

\begin{tabular}{|c|c|c|c|c|}
\hline Subsample & Partner age & Children & City & No. Obs. \\
\hline 1 & Under 45 & No Children & RUC & 87 \\
\hline 2 & Under 45 & No children & Montevideo & 139 \\
\hline 3 & Under 45 & With children & RUC & 442 \\
\hline 4 & Under 45 & With children & Montevideo & 459 \\
\hline 5 & Over 45 & No children & RUC & 360 \\
\hline 6 & Over 45 & No children & Montevideo & 391 \\
\hline 7 & Over 45 & With children & RUC & 221 \\
\hline 8 & Over 45 & With children & Montevideo & 202 \\
\hline
\end{tabular}

RUC: Rest of Urban Country. 
For estimating the income elasiticities of environmental amenities we consider 8 commodities that could be thought of as somehow related to the environment. In particular, we follow the classification of Curiel (1997). In table 2 we present the mean expenditure on each commodity.

$A s$ it is well known, the period of time covered by expenditure surveys are very short and therefore households usually report zeroes in most commodities. 'This fact introduces a sort of measurement error problem when using expenditure or income to measure consumption (see, for example, Meguir and Robin, 1992, among others). In table 3 we present the percentage of zeroes found in expenditures on each commodity.

The number of zeroes is particularly important in some commodities, such as Camping2 or Recreation. Note, however, that in many applications this fact is not considered.

\section{Estimation results}

In this section we present the results of estimating the income elasticities by different methods. Our basic question is whether income elasticity is seriously affected, in terms of qualitative conclusions, by the application of these different methods.

The results are presented in the appendix, tables $4 \mathrm{a}$ to $4 \mathrm{f}$.

The working hypothesis is that the household appreciation of the environment can be deduced from the expenditure on some environmental commodities, i.e., these commodities can be considered as proxies to the environment.

In the first place, we observe that there are serious differences in the estimated income elasticity depending on the estimation method applied. Both, the OLS method and the IV method, tend to overestimate the income elasticity. Remember that these two methods lead to inconsistent estimates in the presence of measurement error. On the other hand, the Hausman et al. and Lewbel methods lead to very similar results in all cases.

In the table 4 the estimates of the income elasticity of the Recreation good are presented, using the four estimate procedures: OLS, IV, Lewbel and Hausman. In the appendix $A$ the estimates for the rest of the selected goods are shown. For each group we carried out the estimates using different samples: the first, second and third income quartiles. 


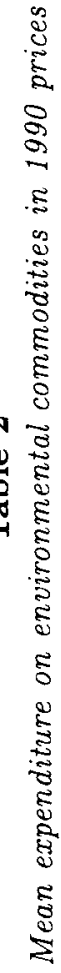

\begin{tabular}{|c|c|c|c|c|c|c|c|c|}
\hline$\underset{J}{\sigma}$ & $\begin{array}{l}\underset{\infty}{\infty} \\
\stackrel{D}{O} \\
\dot{0}\end{array}$ & $\begin{array}{l}\mathscr{6} \\
0 \\
0 \\
0\end{array}$ & $\begin{array}{l}\stackrel{H}{N} \\
\underset{S}{O} \\
\dot{O}\end{array}$ & $\begin{array}{c}\infty \\
\infty \\
\\
0\end{array}$ & $\begin{array}{l}尺 \\
\stackrel{N}{0} \\
\stackrel{0}{0} \\
0\end{array}$ & $\begin{array}{l}10 \\
0 \\
0 \\
0\end{array}$ & $\underset{0}{0}$ & $\stackrel{\mathscr{O}}{0}$ \\
\hline$\underset{5}{5}$ & $\begin{array}{l}10 \\
\delta \\
8 \\
8 \\
0\end{array}$ & $\begin{array}{l}1 \\
8 \\
8 \\
\\
0\end{array}$ & $\begin{array}{l}g \\
\stackrel{g}{8} \\
\stackrel{8}{\circ}\end{array}$ & $\begin{array}{l}E \\
\\
\\
0\end{array}$ & $\begin{array}{l}8 \\
0 \\
8 \\
8 \\
0\end{array}$ & $\begin{array}{l}1 \\
0 \\
\delta \\
\\
0\end{array}$ & $\mid \begin{array}{l}\mathscr{g} \\
8 \\
\\
\\
0\end{array}$ & $\begin{array}{l}8 \\
8 \\
8 \\
8\end{array}$ \\
\hline 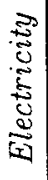 & 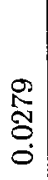 & $\begin{array}{l}\stackrel{10}{\mathcal{N}} \\
\stackrel{\delta}{\delta} \\
\delta\end{array}$ & $\begin{array}{l}\stackrel{\sim}{O} \\
\stackrel{\leftrightarrow}{O} \\
\dot{0}\end{array}$ & 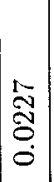 & $\begin{array}{c}\mathscr{N} \\
\delta \\
0 \\
0 \\
\dot{s}\end{array}$ & $\begin{array}{l}\vec{\infty} \\
\stackrel{D}{O} \\
\dot{0}\end{array}$ & $\begin{array}{l}\stackrel{+}{~} \\
\stackrel{\leftrightarrow}{\circ} \\
\stackrel{0}{0}\end{array}$ & 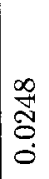 \\
\hline$\underset{\mathrm{E}}{\mathrm{E}}$ & 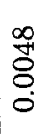 & $\begin{array}{l}\mathscr{\infty} \\
\mathscr{0} \\
\dot{0}\end{array}$ & $\begin{array}{l}\stackrel{m}{i \rho} \\
\delta \\
0 \\
0\end{array}$ & $\begin{array}{c}10 \\
\stackrel{8}{8} \\
0 \\
0\end{array}$ & $\begin{array}{l}\stackrel{D}{0} \\
\stackrel{0}{0} \\
\dot{0}\end{array}$ & $\begin{array}{l}\infty \\
\stackrel{\infty}{\delta} \\
\stackrel{\delta}{\delta} \\
\dot{\sigma}\end{array}$ & 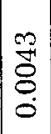 & $\begin{array}{l}\circ \\
\stackrel{8}{8} \\
8 \\
0\end{array}$ \\
\hline 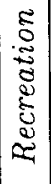 & $\begin{array}{l}\mathscr{c} \\
\stackrel{1}{8} \\
\mathscr{\delta} \\
\dot{0}\end{array}$ & $\begin{array}{l}\infty \\
1 \\
\delta \\
\delta \\
\\
0\end{array}$ & $\begin{array}{l}\vec{S} \\
\delta \\
\\
\dot{0}\end{array}$ & 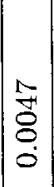 & 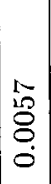 & $\begin{array}{l}\mathscr{g} \\
\delta \\
\delta \\
\\
0\end{array}$ & 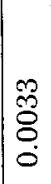 & $\stackrel{0}{\mathscr{H}}$ \\
\hline 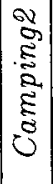 & $\begin{array}{l}\stackrel{N}{\delta} \\
\stackrel{\delta}{\delta} \\
\stackrel{0}{0}\end{array}$ & $\underset{\mathscr{D}}{\tilde{S}}$ & $\mid \begin{array}{c}\stackrel{ }{\mathcal{S}} \\
\stackrel{8}{8} \\
\dot{0}\end{array}$ & $\left|\begin{array}{c}\mathscr{g} \\
\stackrel{\mathcal{O}}{\Xi} \\
\dot{0}\end{array}\right|$ & $\begin{array}{l}m \\
\mathscr{\delta} \\
\delta \\
\delta\end{array}$ & $\left|\begin{array}{c}g \\
\stackrel{\Xi}{O} \\
\stackrel{O}{0}\end{array}\right|$ & $\begin{array}{l}0 \\
0 \\
8 \\
8 \\
0\end{array}$ & 용 \\
\hline $\begin{array}{c}- \\
0 \\
\tilde{E} \\
\tilde{E} \\
\tilde{E} \\
\delta \\
U\end{array}$ & $\begin{array}{l}\stackrel{S}{\mathcal{S}} \\
\text { ปे } \\
\stackrel{0}{0}\end{array}$ & $\begin{array}{l}0 \\
\\
8 \\
0\end{array}$ & $\begin{array}{l}\stackrel{\circ}{\delta} \\
\dot{\delta} \\
\dot{0}\end{array}$ & $\mid \begin{array}{c}\stackrel{8}{\delta} \\
\delta \\
\\
\\
\dot{0}\end{array}$ & $\mid \begin{array}{l}0 \\
\mathscr{\delta} \\
\dot{\delta}\end{array}$ & 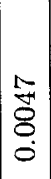 & 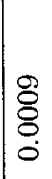 & $\stackrel{\text { 용 }}{8}$ \\
\hline 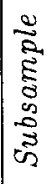 & $\longrightarrow$ & $N$ & $\infty$ & $\forall$ & תמ & $\infty$ & 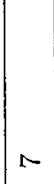 & $\infty$ \\
\hline
\end{tabular}




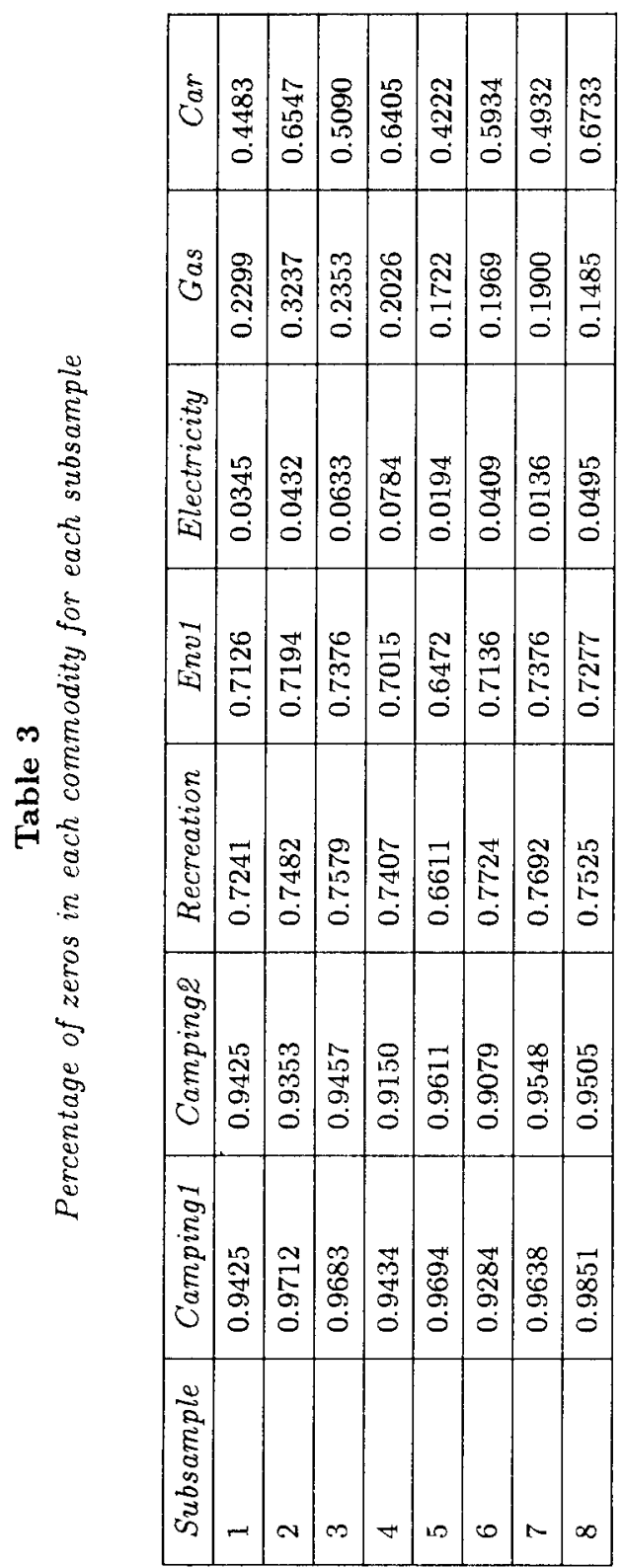




\begin{tabular}{|c|c|c|c|c|c|c|c|c|c|c|c|c|c|c|c|c|c|c|}
\hline \multirow{4}{*}{ 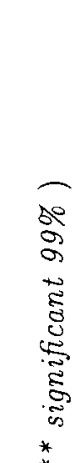 } & \multirow{3}{*}{ 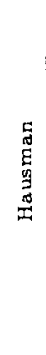 } & $\stackrel{R}{\mathscr{\sigma}}$ & $\begin{array}{l}0 \\
\infty \\
\stackrel{0}{-} \\
-i\end{array}$ & $*$ & \begin{tabular}{l}
$\mathscr{N}$ \\
\multirow{J}{*}{} \\
$\stackrel{i}{ }$
\end{tabular} & $*$ & 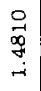 & $*$ & $\begin{array}{l}8 \\
8 \\
0 \\
? \\
-i\end{array}$ & $*$ & 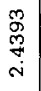 & $*$ & $\begin{array}{l}m \\
\vec{m} \\
\overrightarrow{0} \\
-1\end{array}$ & $*$ & 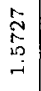 & * & 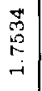 & * \\
\hline & & 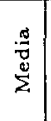 & 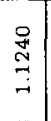 & $\stackrel{*}{*}$ & $\begin{array}{l}\vec{D} \\
\stackrel{D}{0} \\
\text { N }\end{array}$ & * & $\begin{array}{c}\stackrel{9}{*} \\
\underset{\forall}{0} \\
-i\end{array}$ & $\stackrel{*}{*}$ & $\begin{array}{l}\exists \\
\vec{J} \\
\vec{N}\end{array}$ & * & 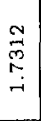 & * & $\begin{array}{l}8 \\
8 \\
0 \\
0 \\
-1 \\
-1\end{array}$ & * & 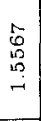 & * & $\begin{array}{l}\infty \\
0 \\
8 \\
0 \\
\dot{\sim}\end{array}$ & * \\
\hline & & $\underset{\widetilde{O}}{\widetilde{O}}$ & $\begin{array}{l}0 \\
0 \\
0 \\
0 \\
0 \\
-1\end{array}$ & & 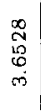 & * & $\begin{array}{l}8 \\
1 \\
\infty \\
心 \\
\sim \\
\sim\end{array}$ & & $\begin{array}{l}g \\
g \\
c \\
m \\
6 \\
0\end{array}$ & $*$ & 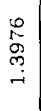 & $*$ & $\begin{array}{l}\underset{3}{\sigma} \\
\stackrel{\leftrightarrow}{*}\end{array}$ & $*$ & $\begin{array}{l}\stackrel{2}{N} \\
\stackrel{N}{N} \\
\stackrel{N}{N}\end{array}$ & * & $\begin{array}{l}0 \\
\infty \\
\infty \\
\infty \\
0 \\
\sim \\
N\end{array}$ & \\
\hline & \multirow{3}{*}{$\begin{array}{l}\overrightarrow{\mathrm{v}} \\
\overrightarrow{0} \\
\overrightarrow{3} \\
\stackrel{y}{\Xi}\end{array}$} & $\stackrel{\stackrel{n}{\circ}}{\sigma}$ & 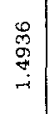 & * & 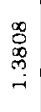 & $*$ & 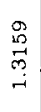 & $*$ & $\begin{array}{c}9 \\
0 \\
0 \\
\stackrel{-}{-1}\end{array}$ & $*$ & 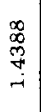 & * & 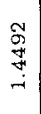 & * & $\begin{array}{l}\stackrel{8}{8} \\
\stackrel{8}{8} \\
-\end{array}$ & & $\begin{array}{l}\vec{\delta} \\
\stackrel{\sigma}{\sim} \\
\stackrel{\sim}{N}\end{array}$ & \\
\hline $\begin{array}{l}50 \\
5 \\
0\end{array}$ & & $\frac{.00}{\tilde{D}}$ & 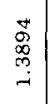 & * & 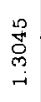 & * & 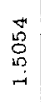 & ${ }_{*}^{*}$ & $\begin{array}{l}0 \\
8 \\
8 \\
0 \\
- \\
-\end{array}$ & $*$ & $\begin{array}{l}\underset{2}{2} \\
\mathbb{1} \\
\infty \\
0 \\
0\end{array}$ & * & $\begin{array}{l}\hat{x} \\
\vec{y} \\
0 \\
0 \\
0\end{array}$ & * & 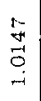 & & $\begin{array}{l}0 \\
8 \\
5 \\
\text { is }\end{array}$ & \\
\hline 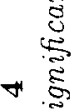 & & $\underset{\sim}{\widetilde{O}}$ & $\begin{array}{l}m \\
0 \\
0 \\
0 \\
0 \\
i\end{array}$ & & $\begin{array}{l}\stackrel{+}{0} \\
\stackrel{1}{\infty} \\
\stackrel{-}{-}\end{array}$ & & $\begin{array}{l}0 \\
2 \\
1 \\
0 \\
0 \\
\sim\end{array}$ & & $\begin{array}{l}0 \\
8 \\
\infty \\
\infty \\
\infty \\
i\end{array}$ & & $\begin{array}{l}m \\
0 \\
0 \\
0 \\
1\end{array}$ & & $\begin{array}{l}n \\
8 \\
8 \\
0 \\
0\end{array}$ & & $\begin{array}{l}\text { 骂 } \\
\text { 品 } \\
9 \\
0 \\
0\end{array}$ & & $\begin{array}{c}\infty \\
\infty \\
\\
m \\
i\end{array}$ & \\
\hline 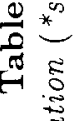 & \multirow{3}{*}{$\geq$} & $\stackrel{n}{\sigma}$ & $\begin{array}{l}2 \\
\stackrel{R}{N} \\
i \\
-i\end{array}$ & * & $\begin{array}{l}\stackrel{P}{\infty} \\
\stackrel{N}{N} \\
\stackrel{N}{N}\end{array}$ & $*$ & $\begin{array}{l}\mathscr{O} \\
\stackrel{0}{\infty} \\
O \\
-\end{array}$ & * & 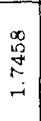 & $*$ & $\begin{array}{c}\tilde{O} \\
0 \\
0 \\
\ddot{\infty}\end{array}$ & $*$ & $\begin{array}{l}\stackrel{0}{\mathscr{D}} \\
\stackrel{+}{+} \\
\stackrel{-}{-}\end{array}$ & $\stackrel{*}{*}$ & 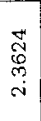 & * & 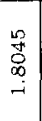 & $*$ \\
\hline है & & $\begin{array}{l}\stackrel{\pi}{J} \\
\stackrel{\Xi}{ \pm}\end{array}$ & $\begin{array}{l}\stackrel{\Delta}{0} \\
0 \\
0 \\
-i\end{array}$ & & $\begin{array}{l}\text { के } \\
\vec{m} \\
\vec{\omega} \\
\text { ल }\end{array}$ & $*$ & $\begin{array}{l}\stackrel{9}{0} \\
\stackrel{0}{p} \\
\text { i }\end{array}$ & $*$ & $\begin{array}{l}\underset{D}{\exists} \\
\vec{\sim} \\
\vec{\sim}\end{array}$ & $*$ & $\begin{array}{l}0 \\
0 \\
0 \\
\infty \\
-1 \\
-1\end{array}$ & $*$ & $\begin{array}{l}\overrightarrow{8} \\
\stackrel{8}{\circ} \\
\sim\end{array}$ & $*$ & 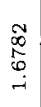 & $*$ & 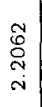 & * \\
\hline 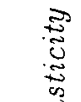 & & $\stackrel{\mathscr{L}}{\sigma}$ & $\begin{array}{l}\infty \\
\tilde{D} \\
0 \\
0 \\
0\end{array}$ & & 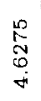 & & $\begin{array}{l}0 \\
\stackrel{0}{*} \\
\vec{H} \\
\dot{m}\end{array}$ & * & 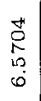 & & 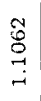 & * & $\begin{array}{l}m \\
\stackrel{m}{m} \\
\vec{\sim} \\
\vec{n}\end{array}$ & * & 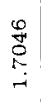 & $\stackrel{*}{*}$ & $\begin{array}{l}8 \\
\stackrel{8}{7} \\
\stackrel{\infty}{n}\end{array}$ & $\stackrel{*}{*}$ \\
\hline 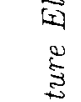 & \multirow{3}{*}{3} & $\stackrel{p}{\sigma}$ & $\begin{array}{l}\hat{D} \\
\mathrm{~g} \\
-1 \\
-1\end{array}$ & * & $\begin{array}{l}\hat{\sigma} \\
\overrightarrow{0} \\
\dot{\omega}\end{array}$ & * & 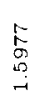 & $*$ & $\begin{array}{l}9 \\
\vec{\forall} \\
\infty \\
0 \\
\stackrel{-}{-1}\end{array}$ & $\stackrel{*}{*}$ & $\begin{array}{l}\stackrel{\sim}{\vec{N}} \\
\hat{\sigma} \\
\stackrel{\sim}{N}\end{array}$ & * & $\begin{array}{l}8 \\
8 \\
2 \\
-2\end{array}$ & * & 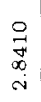 & * & 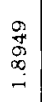 & $\stackrel{*}{*}$ \\
\hline 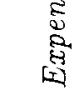 & & $\sum_{\Sigma}^{\frac{d}{z}}$ & $\begin{array}{l}\vec{s} \\
0 \\
\dot{0}\end{array}$ & * & 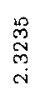 & $*$ & $\begin{array}{l}\infty \\
\stackrel{\infty}{\infty} \\
\stackrel{0}{O} \\
\text { N }\end{array}$ & * & 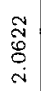 & $\stackrel{*}{*}$ & $\begin{array}{l}\stackrel{-}{-} \\
\infty \\
\infty \\
\stackrel{-}{+}\end{array}$ & $*$ & 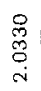 & $\stackrel{*}{*}$ & $\begin{array}{l}\underset{N}{N} \\
\underset{\infty}{\infty} \\
-\end{array}$ & $\stackrel{*}{*}$ & 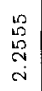 & $\stackrel{*}{*}$ \\
\hline & & $\stackrel{\stackrel{2}{\alpha}}{\sigma}$ & $\begin{array}{l}\tilde{Z} \\
0 \\
-1 \\
-1\end{array} \mid$ & & $\begin{array}{l}b \\
\infty \\
\infty \\
\infty \\
-1 \\
\dot{\omega}\end{array}$ & & $\begin{array}{l}8 \\
8 \\
8 \\
0 \\
\dot{0}\end{array}$ & * & 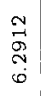 & * & $\begin{array}{l}m \\
m \\
m \\
\rightarrow \\
-\end{array}$ & * & $\begin{array}{l}m \\
n \\
n \\
\sim \\
\sim \\
\sim\end{array}$ & $*$ & $\begin{array}{l}\infty \\
\infty \\
\infty \\
\infty \\
- \\
-\end{array}$ & $*$ & $\begin{array}{l}0 \\
0 \\
\infty \\
0 \\
\sim \\
\sim\end{array}$ & * \\
\hline & & & -1 & & $N$ & & $m$ & & $\pi$ & & น & & $\varphi$ & & 10 & & $\infty$ & \\
\hline
\end{tabular}


It is interesting to highlight two types of results: first the influence of the estimation method on the estimated value of the elasticities, particulaty since these estimates are used in policy design. Second, the focus on the differences in the elasticities for different groups of the population. This would be equal, in a traditional approach, to determining the significance of the different variables that were used to form the subsamples in the explanation of the values taken by the elasticity.

The main hypothesis is that the preferences of the individuals for the environment can be deduced from the expenditures they make in certain goods. These goods (services and camping site products, domestic animals, recreation, etc.) are considered proxies for the environment. At first the environment was generally considered a luxury good. Kriström and Riera (1996) summarize the discussion, sketching the more or less predominant opinion and trying to show that the empirical evidence in certain countries has not matched this hypothesis. In a recent study by Costa (1997) of the US, she finds elasticities for recreation goods greater than one, but with the interesting result that these elasticities have fallen sharply in the past hundred years (from a value of two at the beginning of century to not much more than one at the end of the century).

Kriström and Riera (1996), using estimates for several European countries (Finland, France, Norway, Holland, Spain and Sweden) of their willingness to pay for environmental goods, find, in most cases, that the hypothesis that environmental goods are necessary goods cannot be rejected (their income elasticity is less than one).

In the case of Uruguay, Pereyra and Rossi (1998) using different functional forms of Engel curves and parametric methods, and keeping in mind the selectivity bias (the variables used as proxies for the environment are the same ones used in this work) corroborate the traditional hypothesis that environmental goods are luxury goods.

In this work we especially emphasize non parametric methods and the existence of differences stemming from the methods of estimation. The first conclusion is that in many cases the differences in the estimated elasticities are substantial. To put it in another way, the values of the elasticities obtained are not neutral to the estimation procedures. On the other hand, it is not possible to afirm that a certain estimation method systematically produces higher or smaller values than another.

The following expected result is obtained: the estimates of the elasticities in the first income quartile are larger than the estimates in the second one and these are larger those of the third quartile. These 
results are independent of the estimation method that is used.

The non parametric estimates confirm the hypothesis that the environment constitutes a luxury good in Uruguay.

Complementarily to the estimate of elasticities of those goods considered proxies of environmental goods, the elasticities of goods that might have a negative impact on the environment (electricity, gas and cars) were also considered.

For electricity and gas, elasticities smaller than unity were observed; and for cars the elasticity is higher than one. This shows that during the process of growth the design of policies to control the negative externalities of cars is important.

\section{Conclusions}

The two main conclusions of this study are:

In the first place, we observed serious differences in the estimated income elasticity depending on the estimation method considered. Both, the OLS method and the IV method tend to overestimate the income elasticity. Thus the values of the elasticities are not neutral to the estimation procedures.

Second, the non parametric estimates confirm the hypothesis that the environment constitutes a luxury good in Uruguay.

\section{References}

Banks, J., R. Blundell, and A. Lewbel (1997). "Quadratic Engel curves and consumer demand", The Review of Economics and Statistics, 79.

Costa, D. (1997). Less of a luxury: the rise of recreation since 1888, NBER, Working Paper 6054.

Curiel, F. (1997). La elasticidad de la renta del gasto en recreación ambiental, Universidad Autónoma de Barcelona (manuscript).

Deaton, A. and J. Muellbauer (1980). Economics and consumer behaviour, Cambridge University Press.

Flores, N. and R. Carson (1995). The relationship between the income elasticities of demand and willingness to pay, University of Califomia, (manuscript).

Fry, V. and P. Pashardes (1992). An almost ideal quadratic logarithmic demand system for the analysis of microdata, Oxford Applied Economic Discussion Paper Series, 145.

Gorman, W. M. (1981), "Some Engel curves", in A. Deaton, (ed.), The theory and measurement of consumer behavior, Cambridge, Cambridge University Press. 
Hausman, J. et al. (1991). "Identification and estimation of polynomial errors in variables models", Journal of Econometrics, 50.

Hsiao, Ch. and Q. Wang (2000), "Estimation of structural nonlinear errors in variables models by simulated least squares method", International Economic Review, 41 (2), pp. 523-542.

Instituto Nacional de Estadística (1996). Encuesta de gastos e ingresos, 1994 1995, Montevideo.

Kriström, B. and P. Riera (1997). Income distribution and willingness to pay for environmental goods: some empirical evidence, Universidad Autónoma de Barcelona, (manuscript).

-.. (1996). "Is income elasticity of environmental improvements less than one?", Environmental Resource Economics, (7)1, pp. 45-55.

Lewbel, A. (1987). "Characterizing some Gorman-Engel curves", Econometrica, 55,4 , pp. 1451-1459.

--.- (1996). "Demand Estimation with expenditure measurement errors on left and right hand side", The Review of Economics and Statistics, 78(4), pp. 718-725.

Mammen, E. (1993). "Bootstrap and wild bootstrap for high dimensional linear models", The Annals of Statistics, 21, pp. 255-285.

Meghir, C. and J. M. Robin (1992). "Frequency of purchase and estimation of demand systems", Journal of Econometrics, 53.

Miles, D. (1998). Especificación e inferencia en modelos econométricos de curvas de Engel, PhD dissertation, Universidad Carlos III, Spain.

Newey, W. (1992). Distribution free simulated moment estimation of nonlinear error in variables models, MIT, (manuscript).

Phlips, L. (1983). Applied consumption analysis. Advanced textbooks in economics, North Holland.

Pereyra, A. and M. Rossi (1998). iLos bienes ambientales constituyen un bien de lujo?, DT 13/98, Universidad de Uruguay.

Pollak, R. and T. Wales (1992). Demand system specification and estimation, Oxford University Press. 


\section{Appendix A}

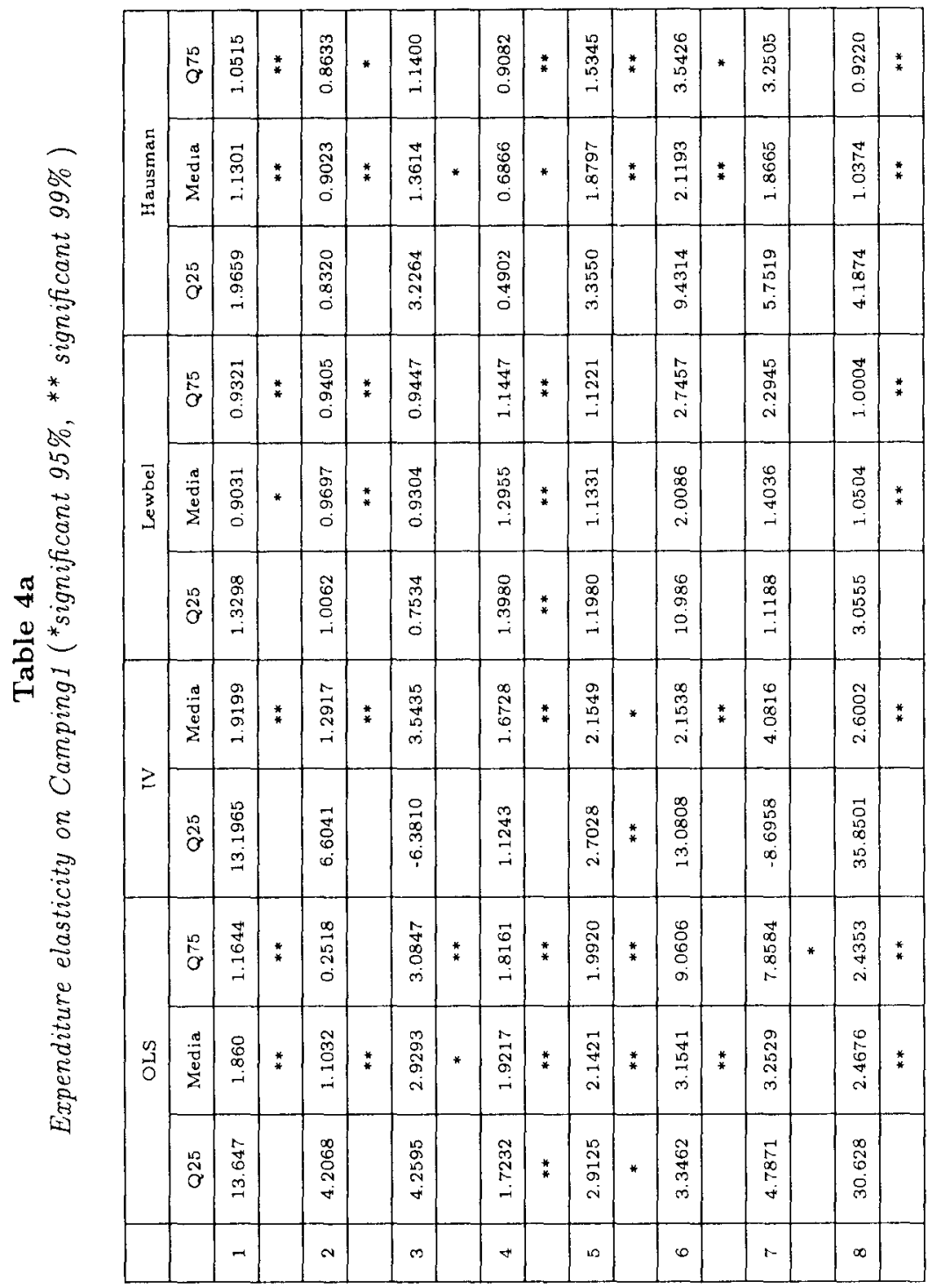




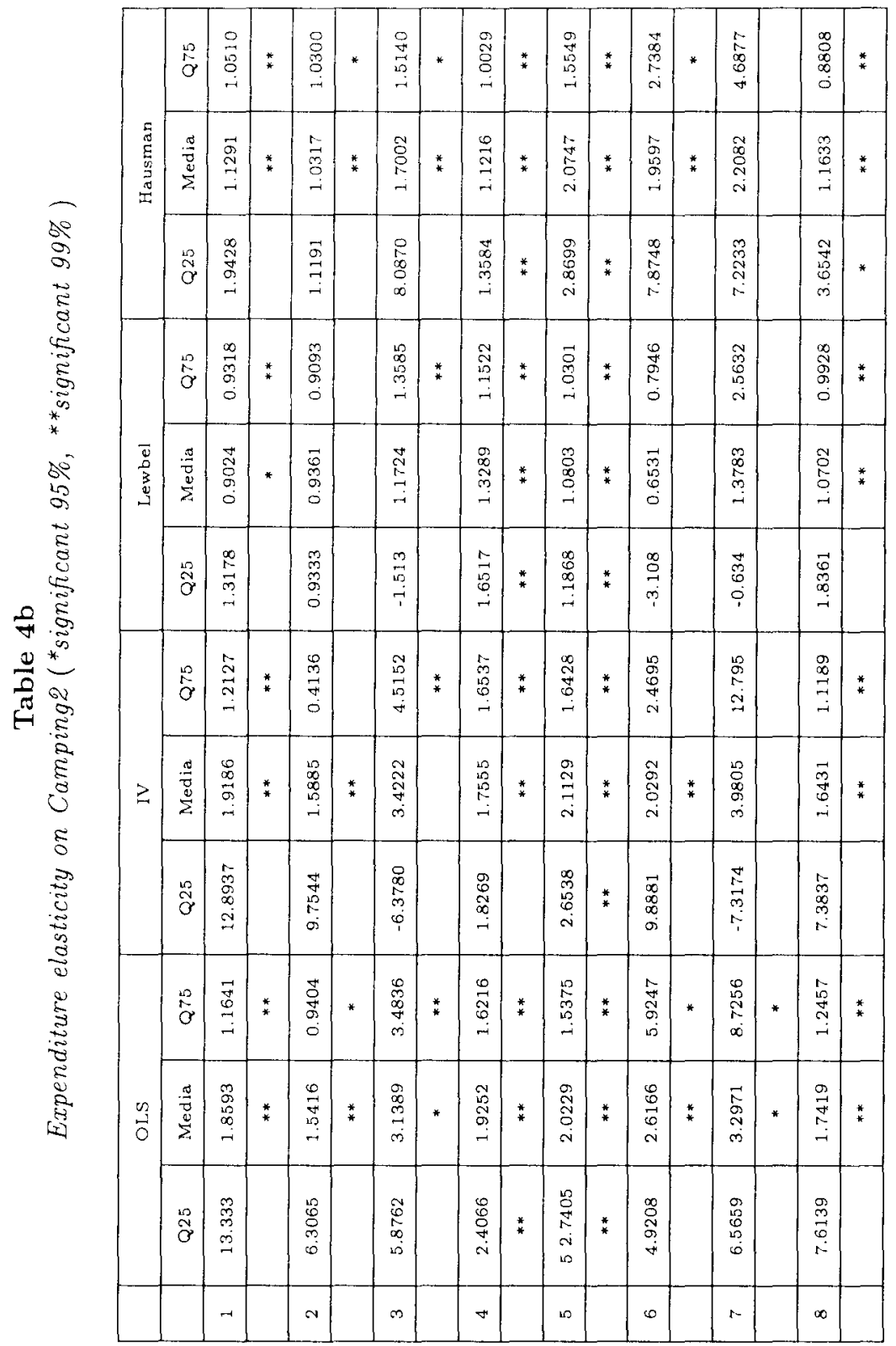




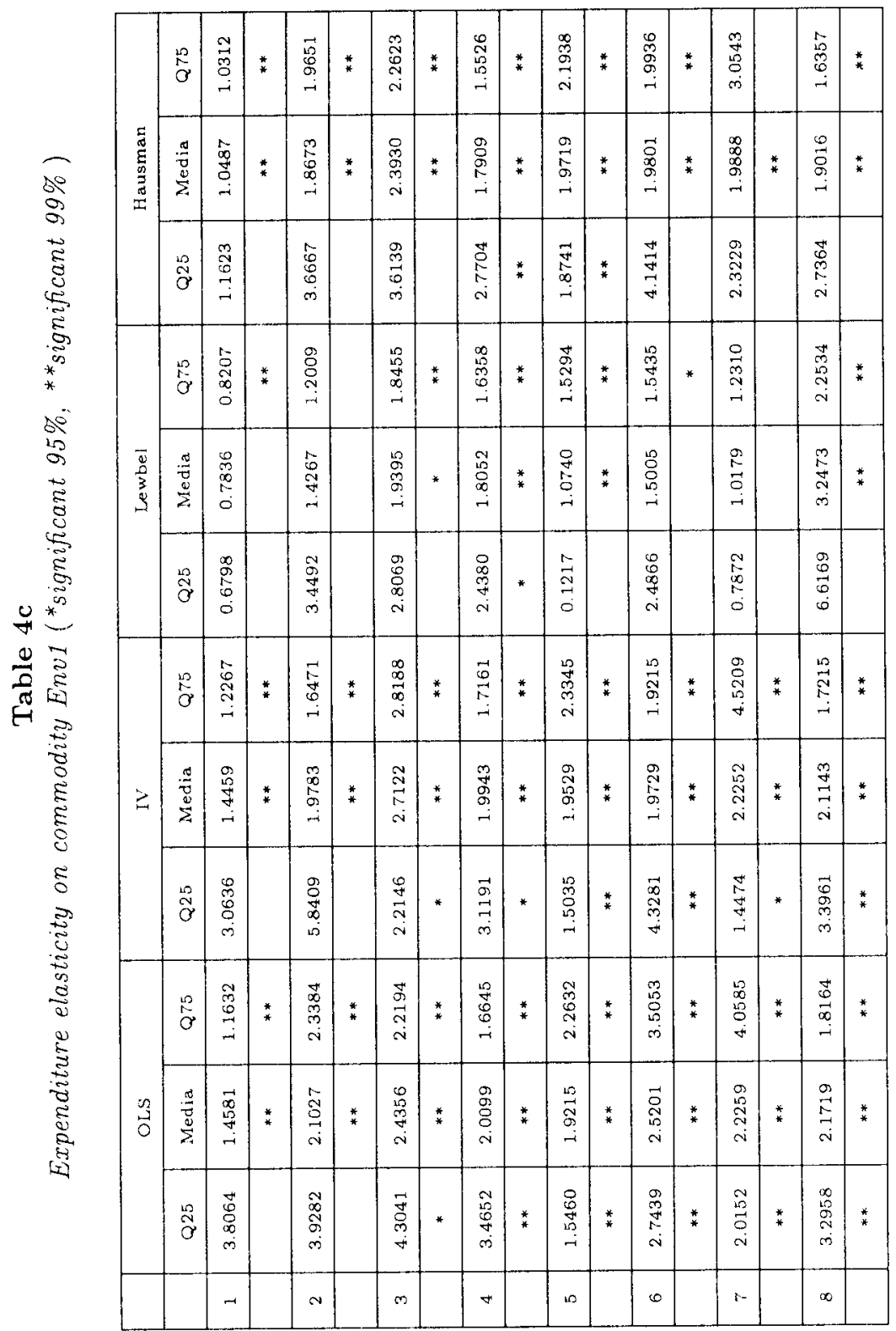




\begin{tabular}{|c|c|c|c|c|c|c|c|c|c|c|c|c|c|c|c|c|c|c|}
\hline & \multirow{3}{*}{ 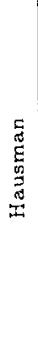 } & $\stackrel{R}{a}$ & $\begin{array}{l}m \\
\overrightarrow{0} \\
0 \\
0 \\
0\end{array}$ & $*$ & $\begin{array}{l}0 \\
\stackrel{0}{心} \\
0 \\
0 \\
0\end{array}$ & & $\begin{array}{l}\infty \\
0 \\
0 \\
0 \\
0 \\
0 \\
0\end{array}$ & * & 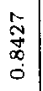 & $*$ & 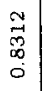 & * & $\begin{array}{l}0 \\
0 \\
0 \\
0 \\
0\end{array}$ & $*$ & $\begin{array}{l}\infty \\
\infty \\
\infty \\
\infty \\
0 \\
0\end{array}$ & * & $\begin{array}{l}\underset{8}{0} \\
0 \\
0 \\
0\end{array}$ & $*$ \\
\hline \multirow{3}{*}{ 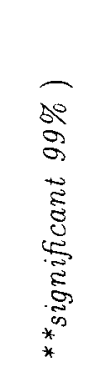 } & & 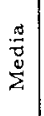 & 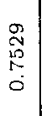 & $*$ & $\begin{array}{l}5 \\
0 \\
0 \\
0 \\
0\end{array}$ & * & 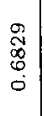 & * & $\begin{array}{c}5 \\
0 \\
12 \\
\infty \\
0 \\
0\end{array}$ & $*$ & 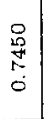 & * & 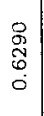 & $*$ & 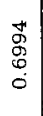 & $*$ & $\begin{array}{l}\infty \\
0 \\
0 \\
1-2 \\
0\end{array}$ & $*$ \\
\hline & & $\stackrel{\mathscr{N}}{\widetilde{O}}$ & $\begin{array}{c}1 \\
10 \\
0 \\
0 \\
0 \\
0\end{array}$ & $*$ & \begin{tabular}{l}
$\hat{S}$ \\
\multirow{3}{6}{} \\
0 \\
0
\end{tabular} & * & $\begin{array}{l}0 \\
8 \\
\stackrel{8}{0} \\
0\end{array}$ & $*$ & $\begin{array}{l}0 \\
0 \\
\infty \\
0 \\
\infty \\
0 \\
0\end{array}$ & $*$ & $\begin{array}{l}0 \\
0 \\
\stackrel{0}{0} \\
0 \\
0\end{array}$ & $*$ & \begin{tabular}{l}
5 \\
\multirow{2}{*}{} \\
1 \\
0 \\
0
\end{tabular} & $*$ & 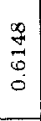 & $*$ & $\begin{array}{l}\infty \\
8 \\
\infty \\
\infty \\
0\end{array}$ & * \\
\hline & \multirow{3}{*}{$\begin{array}{l}\overline{\mathbf{v}} \\
\mathbf{0} \\
3 \\
\underline{3}\end{array}$} & $\stackrel{\substack{R \\
\alpha}}{a}$ & $\begin{array}{l}\infty \\
\infty \\
5 \\
6 \\
0\end{array}$ & $*$ & $\begin{array}{l}\underset{0}{0} \\
\stackrel{B}{b} \\
0 \\
0\end{array}$ & & $\begin{array}{l}0 \\
\overrightarrow{7} \\
0 \\
0 \\
0\end{array}$ & $*$ & $\begin{array}{l}5 \\
R \\
0 \\
0\end{array}$ & $*$ & $\begin{array}{l}\underset{Y}{J} \\
\stackrel{D}{D} \\
\infty \\
0\end{array}$ & $*$ & 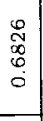 & $*$ & $\begin{array}{l}\infty \\
\stackrel{x}{*} \\
\infty \\
0 \\
0 \\
0\end{array}$ & $*$ & 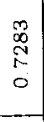 & $*$ \\
\hline \multirow{4}{*}{ 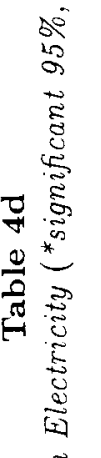 } & & 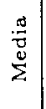 & 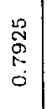 & $*$ & $\begin{array}{l}\text { 总 } \\
0 \\
0 \\
0\end{array}$ & $*$ & $\begin{array}{l}0 \\
\stackrel{7}{3} \\
0 \\
0 \\
0\end{array}$ & $*$ & $\begin{array}{l}\text { of } \\
0 \\
0 \\
i \\
0\end{array}$ & $*$ & $\begin{array}{l}0 \\
0 \\
\infty \\
0 \\
0\end{array}$ & $*$ & $\begin{array}{l}\infty \\
\overrightarrow{0} \\
0 \\
0\end{array}$ & * & 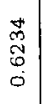 & * & $\begin{array}{c}\infty \\
\infty \\
0 \\
0 \\
0\end{array}$ & $\stackrel{*}{*}$ \\
\hline & & $\stackrel{\stackrel{2}{\mathscr{G}}}{\sigma}$ & $\begin{array}{l}0 \\
0 \\
0 \\
0 \\
0 \\
0\end{array}$ & $\stackrel{*}{*}$ & $\begin{array}{l}2 \\
8 \\
: 0 \\
0 \\
0\end{array}$ & $*$ & $\begin{array}{l}0 \\
\mathscr{D} \\
\mathbb{1} \\
0 \\
0\end{array}$ & * & $\begin{array}{l}\stackrel{*}{0} \\
0 \\
\infty \\
0\end{array}$ & $*$ & $\begin{array}{l}-0 \\
8 \\
0 \\
0\end{array}$ & * & $\begin{array}{l}0 \\
0 \\
0 \\
0 \\
10 \\
0 \\
0\end{array}$ & $*$ & $\begin{array}{l}20 \\
2 \\
10 \\
0 \\
0\end{array}$ & $*$ & $\begin{array}{l}\overrightarrow{0} \\
0 \\
? \\
? \\
0\end{array}$ & * \\
\hline & \multirow{3}{*}{$z$} & 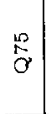 & $\begin{array}{c}0 \\
\hat{1} \\
\infty \\
\stackrel{n}{0} \\
0\end{array}$ & $*$ & 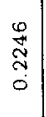 & & $\begin{array}{l}\text { Dे } \\
\stackrel{8}{0} \\
0 \\
0\end{array}$ & * & 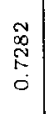 & $*$ & $\begin{array}{c}0 \\
10 \\
0 \\
0 \\
0 \\
0\end{array}$ & $*$ & 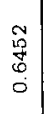 & $*$ & $\begin{array}{l}n \\
5 \\
0 \\
0\end{array}$ & $*$ & $\begin{array}{l}\overrightarrow{0} \\
\overrightarrow{0} \\
0 \\
0\end{array}$ & * \\
\hline & & $\begin{array}{l}\frac{d}{\tilde{g}} \\
\frac{0}{\Sigma}\end{array}$ & 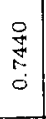 & * & $\begin{array}{l}0 \\
0 \\
8 \\
8 \\
0 \\
0\end{array}$ & $\stackrel{*}{*}$ & $\begin{array}{l}9 \\
\stackrel{0}{0} \\
0 \\
0 \\
0\end{array}$ & $*$ & $\begin{array}{l}0 \\
0 \\
0 \\
\infty \\
0\end{array}$ & $*$ & $\begin{array}{l}N \\
N \\
0 \\
0 \\
0\end{array}$ & ${ }_{*}^{*}$ & $\begin{array}{l}\overrightarrow{0} \\
\overrightarrow{0} \\
\dot{0}\end{array}$ & * & $\begin{array}{l}\overrightarrow{3} \\
\stackrel{8}{\circ} \\
\stackrel{0}{0}\end{array}$ & $*$ & $\begin{array}{l}\hat{\infty} \\
\infty \\
0 \\
0 \\
0\end{array}$ & * \\
\hline \multirow{5}{*}{ 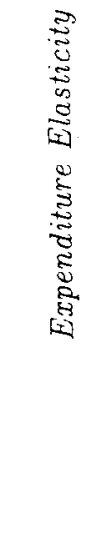 } & & $\stackrel{20}{\sigma}$ & $\begin{array}{l}0 \\
\stackrel{0}{*} \\
\infty \\
0\end{array}$ & * & $\begin{array}{l}- \\
\stackrel{0}{+} \\
\infty \\
0 \\
0\end{array}$ & $*$ & $\begin{array}{l}n \\
n \\
n \\
r \\
0 \\
0\end{array}$ & * & $\begin{array}{l}n \\
\overrightarrow{5} \\
0 \\
0\end{array}$ & $*$ & $\begin{array}{l}R \\
0 \\
0 \\
0 \\
0\end{array}$ & $*$ & $\begin{array}{l}0 \\
0 \\
0 \\
1 \\
0 \\
0\end{array}$ & $\stackrel{*}{*}$ & 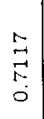 & * & $\begin{array}{l}\infty \\
\infty \\
\infty \\
\infty \\
\infty \\
0\end{array}$ & $*$ \\
\hline & \multirow{4}{*}{ 尔 } & $\stackrel{\stackrel{\circ}{\sigma}}{\sigma}$ & $\begin{array}{l}\frac{1}{0} \\
\frac{D}{5} \\
0 \\
0\end{array}$ & $*$ & $\begin{array}{l}00 \\
\stackrel{0}{0} \\
\dot{m} \\
0\end{array}$ & & $\begin{array}{l}0 \\
: \\
0 \\
10 \\
0 \\
0\end{array}$ & * & $\begin{array}{l}\vec{M} \\
\stackrel{N}{0}\end{array}$ & * & $\begin{array}{l}\stackrel{N}{c} \\
\stackrel{N}{a} \\
0\end{array}$ & * & $\begin{array}{l}0 \\
0 \\
\tilde{D} \\
0 \\
0\end{array}$ & $*$ & 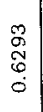 & $*$ & $\begin{array}{l}0 \\
0 \\
0 \\
0 \\
0 \\
0\end{array}$ & $*$ \\
\hline & & $\frac{\pi}{\tilde{E}}$ & $\begin{array}{l}m \\
0 \\
0 \\
0 \\
0 \\
0 \\
0\end{array}$ & $*$ & $\begin{array}{l}\mathbb{N} \\
\mathbb{5} \\
0 \\
0\end{array}$ & $\stackrel{*}{*}$ & $\begin{array}{l}0 \\
0 \\
0 \\
0 \\
0 \\
0\end{array}$ & * & $\begin{array}{l}0 \\
0 \\
0 \\
0 \\
0 \\
0\end{array}$ & $\stackrel{*}{*}$ & $\begin{array}{l}\infty \\
0 \\
0 \\
0 \\
0 \\
0\end{array}$ & $\stackrel{*}{*}$ & 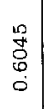 & $*$ & \begin{tabular}{l}
0 \\
\hdashline \\
0 \\
0 \\
0
\end{tabular} & $*$ & $\begin{array}{l}9 \\
\stackrel{9}{0} \\
0 \\
0 \\
0\end{array}$ & $*$ \\
\hline & & $\stackrel{\mathscr{N}}{\mathrm{O}}$ & $\begin{array}{l}\stackrel{0}{\mathcal{N}} \\
\mathbb{F} \\
0\end{array}$ & $\stackrel{*}{*}$ & $\begin{array}{l}8 \\
\mathscr{8} \\
\infty \\
0 \\
0\end{array}$ & $\stackrel{*}{*}$ & 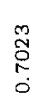 & $*$ & $\begin{array}{l}r \\
0 \\
0 \\
0 \\
0\end{array}$ & $*$ & $\begin{array}{l}0 \\
0 \\
0 \\
0 \\
0\end{array} \mid$ & $\stackrel{*}{*}$ & 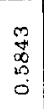 & $\stackrel{*}{*}$ & 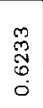 & $*$ & 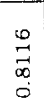 & $*$ \\
\hline & & & $\rightarrow$ & & $N$ & & $m$ & & $\nabla$ & & 10 & & 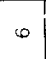 & & 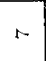 & & $\infty$ & \\
\hline
\end{tabular}




\begin{tabular}{|c|c|c|c|c|c|c|c|c|c|c|c|c|c|c|c|c|c|}
\hline & & $\begin{array}{l}\stackrel{p}{\sigma} \\
\sigma\end{array}$ & $\begin{array}{l}-1 \\
0 \\
0 \\
0 \\
1\end{array}$ & 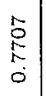 & * & 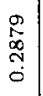 & $*$ & 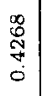 & * & 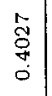 & * & 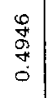 & * & $\begin{array}{l}\infty \\
0 \\
0 \\
0 \\
0\end{array}$ & & $\begin{array}{l}0 \\
\stackrel{\mathbb{J}}{\sharp} \\
\vdots \\
0\end{array}$ & $*$ \\
\hline & 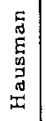 & $\begin{array}{l}\stackrel{d}{g} \\
\stackrel{g}{\Sigma}\end{array}$ & $\begin{array}{l}8 \\
8 \\
0 \\
0 \\
i\end{array}$ & $\begin{array}{c}\hat{N} \\
\stackrel{N}{0} \\
\vdots \\
0\end{array}$ & & $\begin{array}{l}\overrightarrow{\tilde{N}} \\
\stackrel{H}{0} \\
0\end{array}$ & $*$ & $\begin{array}{l}\overrightarrow{3} \\
\stackrel{0}{0} \\
0\end{array}$ & $*$ & $\begin{array}{l}3 \\
6 \\
6 \\
5 \\
0 \\
0\end{array}$ & $*$ & $\begin{array}{l}0 \\
0 \\
0 \\
0 \\
0\end{array} \mid$ & * & $\begin{array}{l}0 \\
0 \\
0 \\
n ٌ \\
0\end{array}$ & $*$ & $\begin{array}{l}\infty \\
0 \\
0 \\
5 \\
0 \\
0 \\
0\end{array}$ & $*$ \\
\hline $\begin{array}{l}\text { se } \\
\text { के }\end{array}$ & & $\stackrel{\mathscr{N}}{\sim} \underset{\sim}{\sim}$ & $\begin{array}{l}\stackrel{0}{0} \\
\stackrel{0}{0} \\
\dot{0}\end{array}$ & $\begin{array}{l}0 \\
\$ \\
\stackrel{+}{-} \\
0 \\
0\end{array}$ & & 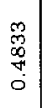 & $*$ & 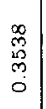 & $\stackrel{*}{*}$ & $\begin{array}{l}0 \\
8 \\
0 \\
0 \\
0\end{array}$ & $*$ & $\begin{array}{c} \pm \\
-1 \\
i \\
0\end{array}$ & $\stackrel{*}{*}$ & $\begin{array}{l}\stackrel{0}{d} \\
\stackrel{5}{0} \\
0\end{array}$ & $*$ & 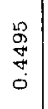 & $\stackrel{*}{*}$ \\
\hline $\begin{array}{l}\tilde{E} \\
\stackrel{\Xi}{E} \\
\stackrel{\Xi}{E}\end{array}$ & \multirow{3}{*}{ 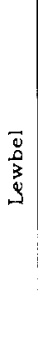 } & $\stackrel{R}{\circ}$ & 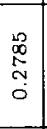 & $\begin{array}{l}- \\
\overrightarrow{-} \\
\overrightarrow{-} \\
\overrightarrow{0}\end{array}$ & & $\begin{array}{c}\infty \\
0 \\
0 \\
⿱ 亠 乂 \\
⿱ \\
0 \\
0\end{array}$ & $*$ & $\begin{array}{l}\hat{0} \\
\hat{2} \\
\vec{b} \\
0\end{array}$ & $*$ & 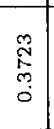 & $\stackrel{*}{*}$ & 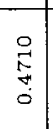 & $\stackrel{*}{*}$ & 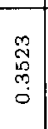 & $*$ & $\begin{array}{l}F \\
\infty \\
0 \\
0 \\
0\end{array}$ & * \\
\hline $\begin{array}{l}* \\
* \\
* \\
10\end{array}$ & & 惫 & $\begin{array}{l}0 \\
0 \\
0 \\
10 \\
0 \\
0\end{array}$ & $\begin{array}{c}N \\
-7 \\
0 \\
i\end{array}$ & & $\begin{array}{l}\vec{m} \\
0 \\
0 \\
\dot{0} \\
\dot{0}\end{array}$ & $\stackrel{*}{*}$ & $\begin{array}{l}0 \\
\stackrel{0}{0} \\
\overrightarrow{0} \\
0 \\
0\end{array}$ & * & $\begin{array}{l}\stackrel{g}{J} \\
\stackrel{5}{0} \\
\vdots \\
0\end{array}$ & $\stackrel{*}{*}$ & 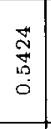 & $*$ & $\begin{array}{l}0 \\
\infty \\
0 \\
0 \\
0 \\
0\end{array}$ & $*$ & $\begin{array}{l}0 \\
0 \\
\forall \\
\forall \\
0\end{array}$ & $*$ \\
\hline 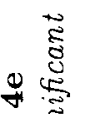 & & $\stackrel{\mathscr{N}}{\widetilde{\sigma}}$ & $\begin{array}{l}m \\
0 \\
0 \\
0 \\
0 \\
0\end{array}$ & $\begin{array}{l}0 \\
\stackrel{3}{4} \\
0 \\
0\end{array}$ & $*$ & $\begin{array}{l}0 \\
1 \\
\\
0 \\
0\end{array}$ & $*$ & $\begin{array}{l}\stackrel{O}{\mathcal{N}} \\
\stackrel{N}{0} \\
\dot{0}\end{array}$ & $*$ & $\begin{array}{l}0 \\
\infty \\
0 \\
0 \\
0 \\
0\end{array}$ & $*$ & $\begin{array}{l}20 \\
0 \\
0 \\
0 \\
10 \\
0 \\
0\end{array}$ & $*$ & $\begin{array}{l}: \\
8 \\
8 \\
0 \\
0\end{array}$ & $*$ & $\begin{array}{l}0 \\
0 \\
0 \\
0 \\
0 \\
0\end{array}$ & $\stackrel{*}{*}$ \\
\hline$\frac{D}{0} \underbrace{\infty}_{\infty}$ & \multirow{3}{*}{$z$} & $\stackrel{R}{\stackrel{R}{\sigma}}$ & $\begin{array}{l}\tilde{D} \\
\stackrel{\tilde{D}}{0} \\
\dot{0}\end{array}$ & $\begin{array}{l}\hat{\sigma} \\
\tilde{O} \\
\delta \\
0 \\
0\end{array}$ & & $\begin{array}{l}\infty \\
\stackrel{\infty}{0} \\
\underset{\sim}{0} \\
\dot{0}\end{array}$ & * & $\begin{array}{l}9 \\
\overrightarrow{7} \\
\overrightarrow{0} \\
0\end{array}$ & $*$ & $\begin{array}{l}\tilde{0} \\
0 \\
0 \\
0\end{array}$ & $*$ & $\begin{array}{l}8 \\
\stackrel{\circ}{0} \\
\stackrel{0}{0}\end{array}$ & & $\begin{array}{l}\stackrel{0}{二} \\
\stackrel{i}{0} \\
0\end{array}$ & & 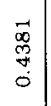 & * \\
\hline \multirow{6}{*}{ 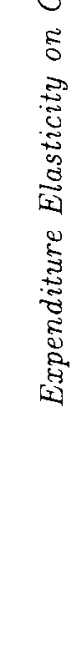 } & & 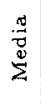 & $\begin{array}{l}0 \\
\stackrel{2}{\sigma} \\
\overrightarrow{0}\end{array}$ & $\begin{array}{l}0 \\
0 \\
0 \\
\stackrel{p}{+} \\
0 \\
0\end{array}$ & $*$ & \begin{tabular}{l}
0 \\
\multirow{y}{*}{} \\
$\dot{y}$ \\
0
\end{tabular} & $*$ & 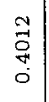 & $*$ & $\begin{array}{l}\infty \\
0 \\
0 \\
0 \\
0 \\
0 \\
0\end{array}$ & $*$ & $\begin{array}{c}0 \\
0 \\
\infty \\
10 \\
0 \\
0\end{array}$ & $\stackrel{*}{*}$ & $\begin{array}{l}\text { 工y } \\
\infty \\
10 \\
0 \\
0\end{array}$ & $*$ & $\begin{array}{l}-1 \\
\overrightarrow{7} \\
0 \\
0\end{array}$ & * \\
\hline & & $\stackrel{\stackrel{\leftrightarrow}{\sim}}{\sigma}$ & $\begin{array}{l}0 \\
0 \\
0 \\
\overrightarrow{0} \\
0 \\
0\end{array}$ & $\begin{array}{l}0 \\
0 \\
0 \\
0 \\
0\end{array}$ & & $\begin{array}{l}0 \\
0 \\
0 \\
10 \\
0\end{array}$ & * & $\begin{array}{l}\infty \\
0 \\
5 \\
m \\
0\end{array}$ & * & $\begin{array}{c}\mathbb{U} \\
- \\
-0 \\
0 \\
0\end{array} \mid$ & ${ }_{*}^{*}$ & $\begin{array}{l}\mathscr{L} \\
\stackrel{0}{o} \\
0 \\
0\end{array} \mid$ & $\stackrel{*}{*}$ & $\begin{array}{l}\stackrel{2}{7} \\
\overrightarrow{0} \\
0 \\
0\end{array}$ & $*$ & 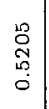 & * \\
\hline & \multirow{4}{*}{$\stackrel{3}{0}$} & $\stackrel{R}{\stackrel{R}{O}}$ & 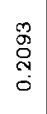 & $\begin{array}{l}\infty \\
0 \\
0 \\
0 \\
0 \\
0\end{array}$ & * & $\begin{array}{l}\vec{B} \\
\stackrel{B}{0} \\
\stackrel{0}{0} \\
0\end{array}$ & * & $\begin{array}{l}\vec{D} \\
\infty \\
\tilde{\omega} \\
0\end{array}$ & ${ }_{*}^{*}$ & $\begin{array}{l}0 \\
\tilde{N} \\
\tilde{D} \\
0 \\
0\end{array} \mid$ & $\stackrel{*}{*}$ & $\begin{array}{c}\stackrel{N}{N} \\
N \\
i \\
0\end{array}$ & * & $\begin{array}{l}\forall \\
5 \\
0 \\
0 \\
? \\
0\end{array}$ & * & $\begin{array}{l}m \\
\stackrel{p}{*} \\
\overrightarrow{0}\end{array}$ & * \\
\hline & & & $\begin{array}{l}\vec{F} \\
\underset{2}{2} \\
0 \\
0\end{array}$ & $\begin{array}{l}N \\
\tilde{D} \\
\tilde{B} \\
0 \\
0\end{array}$ & $*$ & $\begin{array}{c}\mathcal{N} \\
0 \\
0 \\
0 \\
0\end{array}$ & * & 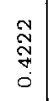 & $*$ & $\begin{array}{l}0 \\
0 \\
0 \\
0 \\
0 \\
0\end{array}$ & $\stackrel{*}{*}$ & $\begin{array}{l}\hat{\sigma} \\
\overrightarrow{0} \\
0 \\
0\end{array}$ & * & $\begin{array}{l}\infty \\
0 \\
0 \\
0 \\
0 \\
0\end{array}$ & * & $\begin{array}{l}\infty \\
0 \\
0 \\
0 \\
0 \\
0\end{array}$ & * \\
\hline & & $\stackrel{\mathscr{N}}{\sigma}$ & 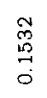 & 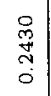 & & $\begin{array}{l}\hat{S} \\
\stackrel{S}{0} \\
0 \\
0\end{array}$ & * & 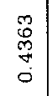 & * & $\begin{array}{l}0 \\
0 \\
0 \\
0 \\
0 \\
0\end{array}$ & * & $\begin{array}{l}0 \\
\stackrel{0}{0} \\
0 \\
0\end{array}$ & * & $\begin{array}{l}- \\
\stackrel{\infty}{*} \\
0\end{array}$ & $\stackrel{*}{*}$ & $\begin{array}{l}\infty \\
\infty \\
\mathbb{N} \\
0 \\
0 \\
0\end{array}$ & $*$ \\
\hline & & & - & $N$ & & $\infty$ & & + & & 12 & & 0 & & $N$ & & $\infty$ & \\
\hline
\end{tabular}




\begin{tabular}{|c|c|c|c|c|c|c|c|c|c|c|c|c|c|c|c|c|c|c|}
\hline & \multirow{3}{*}{ 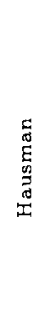 } & $\stackrel{R}{\stackrel{R}{O}}$ & $\begin{array}{l}\stackrel{g}{\Xi} \\
\underset{-}{-}\end{array}$ & * & 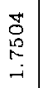 & * & $\begin{array}{l}\overrightarrow{0} \\
\overrightarrow{0} \\
\vec{i}\end{array}$ & $\stackrel{*}{*}$ & 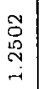 & $\stackrel{*}{*}$ & 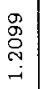 & $*$ & 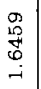 & ${ }^{*}$ & $\begin{array}{l}\stackrel{0}{7} \\
\stackrel{n}{n} \\
\stackrel{-}{-1}\end{array}$ & $*$ & $\begin{array}{l}\text { 先 } \\
\text { 足 } \\
\text { 足 }\end{array}$ & * \\
\hline \multirow{4}{*}{ 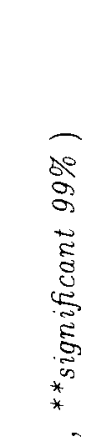 } & & $\begin{array}{l}\stackrel{g}{\Xi} \\
\stackrel{\Xi}{\Sigma} \\
\end{array}$ & 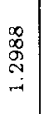 & * & $\begin{array}{l}\vec{J} \\
\overrightarrow{0} \\
\infty \\
-i\end{array}$ & $*$ & 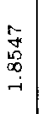 & ${ }_{*}^{*}$ & 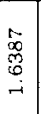 & $*$ & 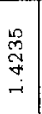 & * & $\begin{array}{c}\vec{D} \\
\infty \\
\infty \\
\stackrel{-}{\mid}\end{array}$ & $*$ & $\begin{array}{l}R \\
\stackrel{2}{0} \\
6 \\
\stackrel{-}{-}\end{array}$ & $*$ & 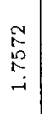 & * \\
\hline & & $\stackrel{\stackrel{\sim}{\sim}}{\sim}$ & 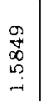 & & 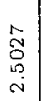 & & $\begin{array}{l}a \\
\vec{I} \\
\vec{\sim}\end{array}$ & & $\begin{array}{l}90 \\
1 \\
b \\
0 \\
i\end{array}$ & $*$ & $\begin{array}{l}0 \\
0 \\
0 \\
0 \\
0 \\
-1 \\
-1\end{array}$ & $*$ & $\begin{array}{l}\vec{g} \\
\stackrel{+}{+} \\
\stackrel{i}{v}\end{array}$ & & $\begin{array}{l} \pm \\
\overrightarrow{8} \\
0 \\
ن \\
ن\end{array}$ & $\stackrel{*}{*}$ & 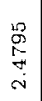 & \\
\hline & \multirow{3}{*}{ 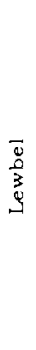 } & 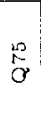 & 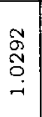 & $\stackrel{*}{*}$ & $\begin{array}{l}\vec{n} \\
\text { 吕 } \\
\infty \\
-1 \\
-1\end{array}$ & * & $\begin{array}{l}3 \\
0 \\
0 \\
\infty \\
-1\end{array}$ & * & 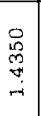 & * & 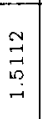 & * & 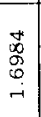 & & 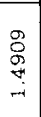 & $\stackrel{*}{*}$ & 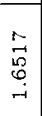 & * \\
\hline & & 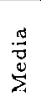 & $\begin{array}{l}\overrightarrow{7} \\
\infty \\
\rightarrow-1 \\
-1\end{array}$ & * & $\begin{array}{l}19 \\
19 \\
0 \\
0 \\
0 \\
N\end{array}$ & * & $\begin{array}{l}\infty \\
\infty \\
心 \\
\cdots \\
\sim \\
心\end{array}$ & * & $\begin{array}{l}3 \\
B \\
E \\
-\end{array}$ & * & $\begin{array}{l}\infty \\
0 \\
\infty \\
\infty \\
- \\
-i\end{array}$ & $*$ & $\begin{array}{l}\overrightarrow{0} \\
\infty \\
0 \\
i \\
ن\end{array}$ & & 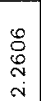 & * & $\begin{array}{l}\overrightarrow{0} \\
\stackrel{N}{N} \\
\vec{i}\end{array}$ & $\stackrel{*}{*}$ \\
\hline 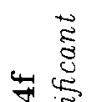 & & 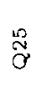 & $\begin{array}{l}\stackrel{8}{\circ} \\
\stackrel{\mathscr{y}}{-} \\
\end{array}$ & & 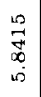 & & $\begin{array}{l}0 \\
0 \\
0 \\
\dot{0} \\
\dot{m}\end{array}$ & & $\begin{array}{l}\bar{\infty} \\
8 \\
8 \\
-\end{array}$ & * & $\begin{array}{l}\underset{\infty}{D} \\
\underset{\infty}{\rightarrow} \\
\infty\end{array}$ & $*$ & 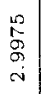 & & 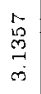 & * & $\begin{array}{l}\mathbb{B} \\
\mathbb{8} \\
0 \\
m\end{array}$ & * \\
\hline$\frac{0}{0} \frac{5}{\infty}$ & \multirow{3}{*}{$\geq$} & $\stackrel{n}{\sigma}$ & 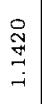 & $*$ & \begin{tabular}{l}
$O$ \\
\multirow{8}{*}{} \\
0 \\
$i$
\end{tabular} & $*$ & $\begin{array}{l}\infty \\
\infty \\
0 \\
0 \\
= \\
=\end{array}$ & * & 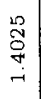 & $\stackrel{*}{*}$ & $\begin{array}{l}\stackrel{\sharp}{0} \\
\stackrel{6}{+} \\
-\end{array}$ & * & $\begin{array}{l}\stackrel{1}{0} \\
\stackrel{0}{0} \\
\stackrel{8}{-} \\
-\end{array}$ & $*$ & 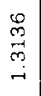 & $*$ & $\begin{array}{l}8 \\
? \\
0 \\
-1\end{array}$ & $*$ \\
\hline \multirow{6}{*}{ 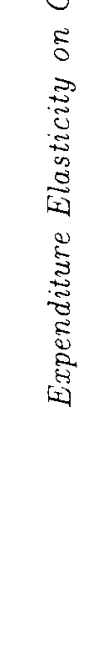 } & & $\frac{\pi}{\pi}$ & $\begin{array}{l}\stackrel{O}{~} \\
\stackrel{8}{+} \\
r i\end{array}$ & * & $\begin{array}{l}8 \\
8 \\
0 \\
\infty \\
-1\end{array}$ & * & $\begin{array}{c}8 \\
\delta \\
\infty \\
\infty \\
-1\end{array}$ & $*$ & $\begin{array}{l}2 \\
R\end{array}$ & * & $\begin{array}{l}\mathscr{0} \\
\stackrel{0}{0} \\
\stackrel{-}{-}\end{array}$ & $\stackrel{*}{*}$ & $\begin{array}{l}\stackrel{\sim}{\mathcal{d}} \\
\stackrel{\sim}{\sim}\end{array}$ & * & 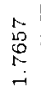 & ${ }_{*}^{*}$ & 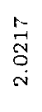 & $\stackrel{*}{*}$ \\
\hline & & 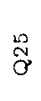 & \begin{tabular}{l}
$\infty$ \\
\multirow{O}{O}{} \\
$\infty$ \\
$\stackrel{-}{-}$
\end{tabular} & & $\begin{array}{l}0 \\
0 \\
0 \\
0 \\
0 \\
-1\end{array}$ & & $\begin{array}{l}\vec{N} \\
\underset{\sim}{\sim} \\
\stackrel{\sim}{\sim}\end{array}$ & * & $\begin{array}{l}0 \\
\infty \\
\vec{J} \\
\vec{\sim} \\
\vec{v}\end{array}$ & $*$ & 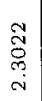 & $\stackrel{*}{*}$ & $\begin{array}{l}0 \\
N \\
\infty \\
\infty \\
\sim \\
\sim\end{array}$ & * & $\begin{array}{l}\vec{n} \\
\stackrel{N}{N}\end{array}$ & $*$ & $\begin{array}{l}\text { N } \\
\text { m } \\
\stackrel{-1}{m}\end{array}$ & $\stackrel{*}{*}$ \\
\hline & \multirow{3}{*}{$\overrightarrow{0}$} & $\stackrel{20}{\stackrel{2}{0}}$ & $\begin{array}{l}\vec{z} \\
\underset{\sim}{ت}\end{array}$ & $*$ & $\begin{array}{l}9 \\
0 \\
0 \\
0 \\
-1\end{array}$ & * & 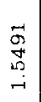 & * & 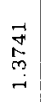 & $\stackrel{*}{*}$ & $\begin{array}{l}n \\
\overrightarrow{0} \\
\tilde{e} \\
-1\end{array}$ & $\stackrel{*}{*}$ & 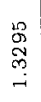 & $*$ & $\begin{array}{l}\infty \\
\stackrel{\infty}{\sim} \\
\stackrel{\sim}{*} \\
-\end{array}$ & $*$ & 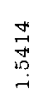 & ${ }_{*}^{*}$ \\
\hline & & $\frac{.}{\tilde{J}}$ & 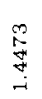 & $\stackrel{*}{*}$ & 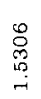 & $*$ & 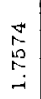 & $\stackrel{*}{*}$ & $\begin{array}{l}\stackrel{2}{\sim} \\
\stackrel{\sigma}{0} \\
\stackrel{0}{0} \\
-\end{array}$ & $*$ & 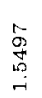 & $*_{*}^{*}$ & $\begin{array}{l}0 \\
8 \\
0 \\
0 \\
--\alpha\end{array}$ & $*$ & \begin{tabular}{l}
$\infty$ \\
$\infty$ \\
\multirow{0}{0}{} \\
$\stackrel{-}{-}$
\end{tabular} & $* *$ & $\begin{array}{l}\infty \\
0 \\
0 \\
\infty \\
\infty \\
+1\end{array}$ & $\stackrel{*}{*}$ \\
\hline & & $\stackrel{\mathscr{N}}{\widetilde{O}}$ & $\begin{array}{l}\frac{m}{2} \\
\stackrel{2}{2} \\
-\end{array}$ & * & 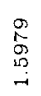 & & $\begin{array}{l}\stackrel{*}{\sharp} \\
\underset{\sim}{\sim} \\
\underset{N}{*}\end{array}$ & $\stackrel{*}{*}$ & $\begin{array}{l}n \\
\vec{g} \\
\stackrel{0}{\alpha} \\
\sim\end{array}$ & $\stackrel{*}{*}$ & 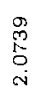 & $*$ & $\begin{array}{l}\infty \\
0 \\
0 \\
0 \\
0\end{array}$ & $*$ & $\begin{array}{l}\infty \\
\overrightarrow{0} \\
\stackrel{0}{2} \\
-1\end{array}$ & $*$ & $\begin{array}{l}0 \\
\stackrel{0}{S} \\
0 \\
\sim\end{array}$ & $\stackrel{*}{*}$ \\
\hline & & & $\rightarrow$ & & $\curvearrowright$ & & $\infty$ & & $\nabla$ & & n & & 0 & & $1-$ & & $\infty$ & \\
\hline
\end{tabular}




\section{Appendix B}

In this appendix we briefly present the Hausman, Newey and Powell (1995) and the Lewbel (1996) methods for estimating an Engel equation in a context of measurement errors.

The Hausman, Newey and Powell (1995) method is based in the following specification. Let the Engel equation be

$$
w_{k}^{*}=g\left(C ; \beta_{k}\right)+\varepsilon_{k}
$$

where $g\left(C ; \beta_{k}\right)=\sum_{s=0}^{S} \beta_{s k} C^{s}, w_{k}^{*}$ is the budget share of good $k, C$ is total consumption and $\beta_{k}$ are the parameters of interest. It is assumed that the reduced equation for total consumption is given by

$$
C=V^{\prime} \alpha+\xi
$$

where the parameters $\alpha$ are unknown and $\xi$ and $V$ are statistically independent with $E(\xi)=0$ and $E\left(\varepsilon_{k} \mid V\right)=0$. The observable variables are total expenditure, $G$, and expenditure share on good $k, w_{k}$, each of which are used to approximate the unobservable variables $C$ and $w_{k}^{*}$ respectively. It is assumed that

$$
G=C+U
$$

and

$$
w_{k}=w_{k}^{*}+\varpi_{k}
$$

with $E\left(\varpi_{k} \mid V, \varepsilon_{k}, \xi\right)=E\left(U \mid V, \varepsilon_{k}, \xi\right)=0$.

The estimation method proposed by Hausman et al. (1991) and Hausman, Newey and Powell (1995) is based on the following three moment conditions

$$
\begin{gathered}
E\left(w_{k} \mid V\right) \int g\left(V^{\prime} \alpha+\xi ; \beta_{k}\right) d F_{\xi} \\
E\left(G w_{k} \mid V\right) \int\left(V^{\prime} \alpha+\xi\right) g\left(V^{\prime} \alpha+\xi ; \beta_{k}\right) d F_{\xi} \\
E(G \mid V)=V^{\prime} \alpha
\end{gathered}
$$

where $F_{\xi}$ is the distribution function of the error term in the instrumental variable equation (Miles, 1998; Hsiao and Whang, 2000; 
Newey, 1992). From the last condition an estimator of $\alpha$ is obtained, and from the first two we can recover $\beta_{k}$. In Miles (1998), simulations of this method are presented which show the appropriate performance of this method under the assumptions for wich it was built.

Lewbel (1996) argues that the problem with the Hausman, Newey and Powell (1995) method is that it does not consider the possibility of a nonlinear measurement error in the dependent variable, which is the case in the estimation of Engel curves. Lewbel proposes a method for consistently estimating the parameters of Engel curves under the presence of nonlinear measurment errors in both the dependent and the independent variables. His method is based on recovering the distribution function of the measurement error using its sequence of moments, and using this distribution to correct the biases introduced by measurement error.

Let the Engel equation be

$$
w_{k}^{*}=\beta_{0 k}+\beta_{1 k} \ln (C)+\beta_{2 k} \ln (C)^{2}+\varepsilon_{k} \quad k=1, \ldots, K
$$

and $G=\sum_{k=1}^{K} G_{k}, w_{k}=G_{k} / G$ are, as before, the observable total expenditure and expenditure share of good $k$.

Then, if $E\left(G_{k} \mid C\right)=E\left(C_{k} \mid C\right)$, the measurement error for good $k$ is given by

$$
G_{k}=C_{k}+v_{k} C
$$

with $E\left(v_{k} \mid C\right)=0$. If $G=C U$, then

$$
w_{k}=\left(w_{k}^{*}+v_{k}\right) / U
$$

which implies that the measurement error of the dependent variable can not be additively separated, as is common in the classical context.

Substituting (A.2) in (A.1), and multiplying by $V G^{q}$, where $V$ is a vector of instrumental variables, assumed to be statistically independent of $u_{k}, v_{k}$, and $G^{q}$ is the total expenditure raised to power $q$, we get

$$
\begin{gathered}
V G^{q} w_{k}=\beta_{0 k} V^{q} C^{q} U^{q-1}+\beta_{1 k} V^{q} C^{q} \ln (C) U^{q-1} \\
+\beta_{2 k} V^{q} C^{q} \ln (C)^{2} U^{q-1}+V^{q} C^{q} U^{q-1} u_{k}+V^{q} C^{q} U^{q-1} v_{k}
\end{gathered}
$$

or

$$
E\left[V G^{q} w_{k}\right]=\beta_{0 k} E\left[V C^{q}\right] E\left[U^{q-1}\right]+\beta_{1 k} E\left[V C^{q} \ln (C)\right] E\left[U^{q-1}\right]
$$




$$
+\beta_{2 k} E\left[V C^{q} \ln (C)^{2}\right] E\left[U^{q-1}\right]+E\left[V C^{q}\right] E\left[U^{q-1} v_{k}\right]
$$

Using the relationship $G^{q}=C^{q} U^{q}$, we can solve for $E\left[V C^{q}\right]$, $E\left[V C^{q} \ln (C)\right]$ and $E\left[V C^{q} \ln (C)^{2}\right]$ to get

$$
\begin{aligned}
E\left[V G^{q} w_{k}\right]= & \alpha_{1 k q} E\left[V G^{q}\right]+\alpha_{2 k q} E\left[V G^{q} \ln (G)\right] \\
& +\alpha_{3 k q} E\left[V G^{q} \ln (G)^{2}\right]
\end{aligned}
$$

with

$$
\begin{aligned}
& \alpha_{1 k q}=\left(\beta_{0 k}-\beta_{1 k} \frac{E\left[U^{q} \ln (U)\right]}{E\left[U^{q}\right]}\right. \\
&+\beta_{2 k}\left(2 \frac{E\left[U^{q} \ln (U)\right]^{2}}{E\left[U^{q}\right]^{2}}-\frac{E\left[U^{q} \ln (U)^{2}\right]}{E\left[U^{q}\right]}\right) \\
&\left.+\frac{E\left[U^{q-1} v_{k}\right]}{E\left[U^{q-1}\right]}\right) \frac{E\left[U^{q-1}\right]}{E\left[U^{q}\right]} \\
& \alpha_{2 k q}=\left(\beta_{1 k}-2 \beta_{2 k} \frac{E\left[U^{q} \ln (U)\right]}{E\left[U^{q}\right]}\right) \frac{E\left[U^{q-1}\right]}{E\left[U^{q}\right]} \\
& \alpha_{3 k q}=\beta_{2 k} \frac{E\left[U^{q-1}\right]}{E\left[U^{q}\right]} .
\end{aligned}
$$

If, in (A.5)-(A.7) $q=1$, with $E\left[U^{q}\right]=0$ for $q=0,1$, we get

$$
\begin{gathered}
\beta_{0 k}=\alpha_{1 k q}+\alpha_{2 k q} E[U \ln (U)]+\alpha_{3 k q} E\left[U \ln (U)^{2}\right] \\
\beta_{1 k}=\alpha_{2 k q}+2 \alpha_{3 k q} E[U \ln (U)] \\
\beta_{2 k}=\alpha_{3 k q} .
\end{gathered}
$$

From the last equation we see that $\beta_{2 k}$ is identified, but for recovering $\left(\beta_{0 k}, \beta_{1 k}\right)$ we need to estimate $E[U \ln (U)]$ and $E\left[U \ln (U)^{2}\right]$.

For this, we first estimate the alphas using equation 


$$
G^{q} w_{k}=\alpha_{1 k q} G^{q}+\alpha_{2 k q} G^{q} \ln (G)+\alpha_{3 k q} G^{q} \ln (G)^{2}+\varepsilon_{k q}
$$

Second, with $\alpha_{k q}=\left(\alpha_{1 k q}, \alpha_{2 k q}, \alpha_{2 k q}\right)^{\prime}$ we use condition (A.7) to recover the moments of the distribution function of the measurement error, $U$. From this condition, if $\mu_{q}=E\left(U^{q}\right)<\infty$, for $q>1$, we get

$$
\mu_{q}=\alpha_{3 k 1}^{q-1} \prod_{j=2}^{q}\left(\alpha_{3 k j}^{-1}\right)
$$

which is the sequence of moments of the distribution of the measurement error. Then, Lewbel assumes that the distribution of the measurement error is log-normal, so we have that

$$
E\left(U_{h} \ln \left(U_{h}\right)\right)=\ln \left(\alpha_{3 k 1} / \alpha_{3 k 2}\right) / 2
$$

and

$$
E\left(U_{h} \ln \left(U_{h}\right)^{2}\right)=\ln \left(\alpha_{3 k 1} / \alpha_{3 k 2}\right)\left(1+\ln \left(\alpha_{3 k 1} / \alpha_{3 k 2}\right) / 2\right)
$$

Finally, the method developed by Miles (1998) is based on the following specification of the Engel curve,

$$
w_{k}^{*}=g\left(C ; \beta_{k}\right)+\varepsilon_{k}
$$

where $g(\cdot)$ is any theory consistent specification, $w_{k}^{*}=C_{k} / C$, is the true budget share proportion of good $k$ and $C$ is total consumption. Also, we have the following instrumental variable equation for total consumption

$$
C=V^{\prime} \alpha+\xi
$$

such that $V$ and $\xi$ are statistically independent. We do not observe $C$ nor $w_{k}^{*}$, but instead we observe expenditure in good $k, G_{k}$ and total expenditure, $G$, with the following measurement errors,

$$
\begin{gathered}
G_{k}=C_{k}+U_{k} \\
G=C+U
\end{gathered}
$$

such that $E\left(U_{k} \mid V\right)=E(U \mid V)=0$ 
Miles (1998) proposes a method based on two of the three moment restrictions on which the Hausman, Newey and Powell (1995) method is based. Based on

$$
\begin{gathered}
E\left(G_{k} \mid V\right)=\int\left(V^{\prime} \alpha+\xi\right) g\left(V^{\prime} \alpha+\xi ; \beta_{k}\right) d F_{\xi} \\
E(G \mid V)=V^{\prime} \alpha
\end{gathered}
$$

if we denote $q\left(V^{\prime} \alpha+\xi ; \beta_{k}\right)=\left(V^{\prime} \alpha+\xi\right) g\left(V^{\prime} \alpha+\xi ; \beta_{k}\right)$, we could write a Taylor expansion around the mean of $\xi$, getting

$$
E\left(G_{k} \mid V\right)=q\left(V^{\prime} \alpha ; \beta_{k}\right)+\sum_{j=2}^{\infty} \frac{q^{j}\left(V^{\prime} \alpha ; \beta_{k}\right)}{j !} \int \xi^{j} d F_{\xi}
$$

where

$$
q^{j}\left(V^{\prime} \alpha ; \beta_{k}\right)=j g^{j-1}\left(V^{\prime} \alpha ; \beta_{k}\right)+\left(V^{\prime} \alpha\right) g^{j}\left(V^{\prime} \alpha ; \beta_{k}\right)
$$

is the $j-t h$ derivative of $q\left(C ; \beta_{k}\right)$ evaluated at $V^{\prime} \alpha$. If $E\left(\xi^{j}\right)<\infty$, for $j>1$, (Lewbel, 1996), then we could rewrite

$$
E\left(G_{k} \mid V\right)=q\left(V^{\prime} \alpha ; \beta_{k}\right)+\lim _{J \rightarrow \infty} \sum_{j=2}^{J} \gamma_{j} \frac{q^{j}\left(V^{\prime} \alpha ; \beta_{k}\right)}{j !}
$$

where $\gamma_{j}=\int \xi^{j} d F_{\xi}$. Note that if $q\left(V^{\prime} \alpha ; \beta_{k}\right)$ is linear in $\beta_{k}$, then the derivatives, $q^{j}\left(V^{\prime} \alpha ; \beta_{k}\right)$, will also be linear. Therefore, the expansion will be a linear specification where the dimension of the parametric space will depend on the order of the expansion. If it is assumed that the order of the expansion depends on the size of the sample, $J=J(n)$, such that $J(n) \rightarrow \infty$ when $n \rightarrow \infty$, then the parametric space will depend on $n$. Mammen (1993) has proposed an $F$ based test, whose distribution is approximated by bootstrap, for testing the dimension of the parametric space, and hence, the order of the expansion to be considered. 
